\title{
DIE GEREFORMEERDE EKUMENIESE SINODE TE AMSTERDAM 1968 EN DIE VROU IN DIE AMP
}

\section{Oorsig van gelewerde resultate}

\subsection{Deputaterapport, Res Acta 1968, Bylae 4, bl. 144 e.v.}

1.1.1. Mandaat: Die G.E.S. te Grand Rapids 1963 het deputate benoem met die opdrag ,to examine in the light of Scripture the general reformed practice of excluding women from the various ordained offices in the church.

1.1.2. Rapport. Die Rapport (bylae 4) is ook deur 'n kommissie ter sinode (art. 62) opgesom. Die rapport sê: Die O.T. noem enkele uitsonderlike gevalle waar vroue as profetesse of koningin-moeders opgetree het, maar gee geen afdoende getuienis ,about the question whether woman in the christian church has to be excluded from a clerical function or not". Die slotsom is eerder: „In general women did not have any official function in the time of the Old Testament". Die O.T. is ,inconclusive in determining the role which a woman may fill in the New Testament Church".

Die evangelies vermeld vroue wat die Here gedien het. Enkele gissings ("may perhaps”, „could be an indication”, bl. 145) word aan die hand gedoen, maar daar is geen „unequivocal answer" op die vraagstuk nie.

Handelinge sê manne is tot die ampte verkies (Hand. $1: 21$, $26 ; 6: 3$ ), maar die gawe van die Gees is ook aan vroue gegee. Bevestiging (Hand. 14:23) is noodsaaklik, maar "the line between charisma and ministry was rather flexible" en daar was nie 'n terminus technicus vir „ministry” nie.

Die briewe van Paulus lê onbetwisbaar 'n vroueaktiwiteit in die kerk bloot (bid, profeteer, 1 Kor. 11 : 5 ; medewerkers, Rom. $16: 3,6,12$; Fil. $4: 2,3$; weduwees met kwalifikasies, 1 Tim. $5: 3$ 16 ; vroue, $3: 11$; Titus $2: 3$, en veral Phoebe, Rom. $16: 1$, diakonon tes ekklesias). Aandag is gegee aan die swyggebooie (1 Kor. $14: 34$; 1 Tim. 2 : 12, Acta bl. 146v). Die vraag waarom die swyggebooie vroue van die amp uitsluit, word beantwoord met verwysing na "the fact that at the time and in the circumstances in which the young church was living, public actions on the part of the woman were concidered indecent", en aan die ander kant hou Paulus juis in Gal. $3: 28$ en Ef. $2: 13$ teenoor die Judaïste vol dat vroue nie ,second grade members" is nie (bl. 147).

Daarteenoor word die gangbare ,in our time" en die moderne „society" na vore gebring. Eksegese wat egter rekening hou met die besondere roeping en differensiasie van die vrou lê die deputate met ,be that as it may" (bl. 148) eenkant. Dit word toegegee dat Paulus ,is not entirely clear to us" (bl. 148). Hy word egter gelees in die lig van ,certain times and under certain circumstances". 
Daar is vandag gissinge moontlik (,one may wonder”, bl. 149) omdat vroue nie meer so jonk trou nie. Nietemin word stellig gekonkludeer dat die "subordination of woman in the Church" onhoudbaar is ,in a time when the woman, in all fields of life, is acting as an „equal" of the man and is in fact as such accepted by us Christians. Can this dualism be the meaning of the Holy Scripture (bl. 159)?"

Enkele feite i.v.m. die vroue in die oudste Christelike Kerk (bl. 149 e.v.) dui andermaal op vroulike aktiwiteit, hoewel hulle nie in die besondere ampte betrek is nie. Calvyn en Voetius het wel 'n plek vir hulp-diakonesse ingeruim. Die vraag of die diakonesse volkome ekwivalent aan die "manlike" diakens en of hulle slegs helpers vir die diakens was, bly onbeantwoord. Die rapport spring ligtelik van „auxiliary forces” oor na „official ecclesiastical function” (bl. 156).

Die toelating van vroue tot besondere ampte in protestantse kerke is almal van heel resente datum (bl. 156 e.v.).

\section{Voorlopige kritiese opmerkings oor die rapport}

2.1. Kritiek van die kommissie van preadvies, res acta 1968, art. 62.

Die Kommissie van die G.E.S. toon aan dat die argumentasie van die deputaterapport onoortuigend is. Die aandag word veral op die volgende gevestig: Die Skrifgegewens in 1 Kor. $11: 5$; Rom. $16: 1 \mathrm{v}$, en 1 Tim. $5: 3-16 \mathrm{kan}$ as 'n heel besondere tipe diens verstaan word. Dit dwing nie tot konklusies oor die besondere ampte nie.

1 Tim. 2 : 12 , Ef. $5: 22-24$ en Gen. $2: 18$ is onbevredigend behandel. Die "similarity or identity" van die diens van die weduwees en dié van huidige diakens is "questionable". 1 Kor. 14 : 34 en 1 Tim. 2 : 12 word geplaas ,in the broader context of equality posited in Gal. $3: 28$, but the jump is here made from general membership to the privilege of the exercise of the special offices of the church". Die verwysing na 1 Kor. $12: 7$, is a bit unclear, at least indecisive". Die kardinale eksegetiese vraagstuk wanneer Paulus juis "inequality" tussen man en vrou afwys maar tog "difference" op grōnd van die skeppingsleer, is nie geweeg en beantwoord nie. "How can the Church proceed with the implementation of the thesis "that woman can only assume such functions in the church as will harmonize with her nature" if that Biblical picture of her created nature and function in society has not been determined?" Hier kom die probleme rondom die getuienis in Gen. $2: 18,1$ Tim. $2: 12$, Ef. $5: 22-24$ vierkantig na vore.

¥.v.m. 1 Kor. $14: 34$ en 1 Tim. $2: 12$, „we are left hanging by the study report, with the question: "To what extent must the two pronouncements of the apostle, however absolute and binding they may seem to be for all times, be interpreted in this sense?" Dan volg die slotsom: „The basic question remains unanswered 
wether or not there is a basic created natural place and function of the woman subservient to the man and wether that will determine or qualify the structural relation of man and woman in the church of Jesus Christ".

\subsection{Verdere kritiese opmerkings}

2.2.1. Klaarblyklike Skrifgegewens is in die Rapport nie genoem nie, terwyl oor gebrekkige gegewens i.v.m. die vroue breed gespekuleer word. In Handelinge kom wel 'n bepaalde benadering of beskrywing - 'n bepaalde begrip en siening - van die geïnstitueerde kerk na vore: presbuteros (Hand. $11: 30,14: 23,15: 2,4$, $6,22,23,16: 4,20: 17)$; adelphos $(2: 37,3: 22,7: 37,6: 3$, $11: 29,12: 17,15: 3,22,23,33,36,22: 7$, ens., ens.); Andres (Hand. $2: 29,6: 3$ ).

Manne vorm dus die adres van die gemeente en die gemeente word soms net as manne aangespreek. Die vanselfsprekende natuurlike veronderstelling van die Skrif is dat „broeders" en "manne” die voorstanders in die gemeente is. Die gangbare algemene begrip $a m p$ ("narrow señse of the ministry of clergyman, elder and deacon") loop in die Skrif in die bedding van adelphos of andres, want 'n abstrakte saamvattende begrip ,amp" vir onderskeie dienste of funksies is onbekend.

Die besondere „ministry" word reeds tegnies met 'n naam presbuteros of episkopos (Hand. $20: 28$ ) aangedui. Wanneer na dienaars sonder 'n terminus technicus verwys word (ongeag die vraag asof dit op die diakens slaan of nie), is die woord "manne" voldoende. Hand. 6 sê manne is vir die omskrewe diens bevestig. Die Skrifgegewens toon dat dit gevaarlik en foutief kan wees om die moderne idee van ,ampsdraer" (office bearer, art. 183) of „clerical function" met die Bybel te wil verklaar - of in die Bybel in te lees.

2.2.2. Aktiwiteit van gelowiges word verwar met ampsbekleding en verraai ' $n$ fundering van die amp in die bekleder daarvan (aktivistiese en antroposentriese ampsbeskouing). Die feit dat vroueaktiwiteit (net soos 'n breër-manne-aktiwiteit) voorkom, bewys niks ten opsigte van die toelating van vroue tot die dienste van diakens, ouderlinge of predikante nie. Die afleiding sou slegs opgaan indien elke man wat aktief helper of dienskneg van die gemeente is per se in een van die besondere dienste moes staan. Is kerklike aktiwiteit tot die "ampte" beperk? Sou 'n aktiewe manslidmaat, wat nie tot ' $n$ besondere amp verkies word nie, gesubordineer of ongelyk wees aan sy broeder wat wel 'n besondere amp beklee? Is daar 'n ,inequality" - 'n vertikale onderskeid - tussen ampsdraer en limaat, clerus en leke?

2.2.3. Is die kultuur-historiese argument so normatief dat die Skrif daarmee afdoende verklaar kan word? Is ons moderne same- 
lewing normatief vir die kerklike inrigting? Is die gevaar nie wesenlik dat moderne opvattinge ingedra word en die Skrif aan 'n proses van „ontmitologisering" van ,destydse omstandighede" in die lig van „moderne" gebruike onderwerp word nie?

Die Skrifgegewens en historiese plek van die vrou bewys duidelik dat funksie, taak of aktiwiteit in die gemeente op sigself niks omtrent die besondere ampte kan verduidelik nie. Kerklike aktiwiteit en plig is nie sinoniem vir besondere ampte nie. Die aktiwiteit in die ,amp van die gelowige" sal in baie opsigte analoog wees met die "besondere amp" - omdat laasgenoemde niks aan die gemeente toevoeg nie, maar slegs uitdruk wat in die gemeente gegee is.

2.2.4. Skrifgegewens deur dr. J. D. Vorster voorgelê aan die Studiedeputate vir die Afrika-streek (G.E.S. Acta, bl. 353).

2.2.4.1. Vroue is in die O.T. nie toegelaat om die priesterlike diens te vervul nie. Wel het vroue by die ingang van die tent van samekoms gedien (1 Sam. $2: 22$ ) en het die profeet Joël voorspel dat God sy Gees op alle vlees sou uitgiet, mans en vroue, en dat „julle seuns en julle dogters sal profeteer". Nêrens is daar egter enige aanduiding dat hulle amptelik priesterlike diens gedoen het nie.

2.2.4.2. In die N.T. is daar vroue-dissipels maar geen vroueapostels nie. Onder die dissipels van die Here was daar ook vroue ,wat vir Jesus van Galilea af gevolg het en Hom gedien het" (Matt. $27: 55$ ). Daar was vroue wat eervol vermeld word om hulle geloof (Joh. $12: 1-8$ ). En tog het die Here Jesus Christus toe Hy die apostels gekies het nie een vrou geneem nie. Dit is veelseggend as in gedagte gehou word dat sommige van die vroue meer bekend vir hulle geloof en diens was as sommige van die apostels. 'n Vrou, Maria, was die eerste boodskapper van die opstanding. Hierby moet in aanmerking geneem word dat alle besondere ampte later in die amp van apostel opgesluit was.

Hierdie feite kry meer aksent as ons in Handelinge lees dat sewe mans as diakens aangewys is juis toe hulle dienswerk onder andere die versorging van weduwees ingehou het (Hand. $6: 1$ ). Handelinge verhaal dat Dorkas "oorvloedig in goeie werke en aalmoese was". Dit is duidelik dat haar werk persoonlik en nie amptelik was nie (Hand. $9: 36$ ). Daar was ook vroue met ander spesiale gawes soos die dogters van Filippus „wat die profetiese gawe besit het". Hoewel hulle vader 'n diaken was, is daar geen aanduiding dat hulle amptelik gedien het nie.

2.2.4.3. In die N.T. is vroue-aktiwiteite sonder besondere ampsbekleding: Uit 1 Kor. $11: 5$ v; 1 Kor. $14: 12,23,26,31$ 34; Efese $4: 12$; Rom. $12: 1$; 1 Tim. $2: 1 ; 1$ Tim. $3: 11$; Gal. $3: 28$; Titus $2: 3$ is duidelik dat die apostel nie die vrou minderwaardig beskou of an die man ' $n$ meer verhewe status in Christus toeken nie. Nee, hy skryf juis aan die Galasiërs $(3: 28)$ : „Daar is nie meer man en vrou nie, want hulle is almal een in Christus Jesus". Die Apostel vermeld dan ook verskillende vroue eervol vir hulle arbeid in die 
gemeentes (Rom. 16:1-12; Fil. $4: 3$ ). In hierdie Skrifgedeeltes is geen aanduiding dat hulle in ' $n$ besondere amp werksaam was nie. Hulle is nie tweedeklas lidmate nie. Hulle word nie uitgeskakel uit die gemeenteprogram nie, maar word juis geprys vir hulle besondere arbeid.

2.2.4.4. Die swyggebooie bewys juis dat vroue in die gemeentes kon spreek.

In 1 Kor. $14: 34$ en 35 leer die apostel duidelik „Julle vroue moet in die gemeentes swyg; want dit is hulle nie toegelaat om te spreek nie, maar om onderdanig te wees soos die Wet ook sê. Maar as hulle iets wil leer, laat hulle tuis hulle eie mans vra, want dis lelik vir vroue om in die gemeente te spreek". Uit vers 36 is dit duidelik dat vroue in Korinthe hulle wel veroorloof het om in die gemeente te spreek. Dit is in Korinthe wel toegelaat, maar die apostel keur dit af en wel op grond dat dit in stryd met die Wet is en nie omdat dit in die tyd nie gebruiklik was nie. Die Wet bepaal dat die vrou onderdanig moet wees. Calvyn sê tereg in sy kommentaar: „I reply that the task of teaching is one that belongs to someone with oversight, and is for that reason inconsistent with being in subjugation. For how unsuitable it would be for a woman, who is in subjugation to one of the members, to be in an authoritative position over the whole body!" Die feit dat die apostel hom op die Wet beroep bewys dat hy die praktyk veroordeel in die lig van die Woord van God en dat hy hom nie akkommodeer aan bestaande gebruike en opvattinge oor die openbare optrede van vroue nie.

2.2.4.5. Die openbare verhouding tussen man en vrou wortel in die skepping en sondeval:

In 1 Tim. $2: 11-14$, stel die apostel dat hy die vrou nie toelaat "om onderrig te gee of oor die man te heers nie". Hier beroep hy hom op die skeppingsorde en die sondeval. Ook hier gaan dit nie oor wat in daarilie tyd geoorloof was nie. Die apostel beroep hom op twee dinge: Adam is eerste gemaak, hy is die hoof ,soos Christus ook hoof van die gemeente is" (Efese 5 : 23); en tweedens „Adam is nie verlei nie, maar die vrou het haar laat verlei en het in oortreding gekom". Die verlossingswerk van Christus het dit nie in hierdie bedeling opgehef nie, net so min as wat dit die oordeel dat sy met smart kinders sal baar opgehef het. Dis duidelik dat ons hier met 'n gebod te doen het wat vir alle tye geldig is ondat dit wortel in die skepping en ook noodsaaklik is as gevolg van die sondeval.

Sommige het wel uit Titus $2: 3$, waar vroue vermaan word om leraresse van wat goed is, te wees, afgelei dat hulle wel kon leer. Hierdie opvatting onderskei egter nie tussen die roeping van die mens, man of vrou, in die amp van gelowige en die roeping tot die besondere amp nie. Sommige het van 1 Tim. $3: 11$ „, net so moet die vroue waardig wees" afgelei dat hier vroue in die amp bedoel 
word. Waar vers 11 tussen verse 10 en 12 staan wat albei oor diakens spreek, is dit voor die hand liggend dat hier vroue van diakens bedoel word. Maar selfs as dit nie die bedoeling sou wees nie, moet Bouma se kommentaar aanvaar word „Dat deze vrouwen een kerkelijk ambt hebben bekleedt, leert dit Woord niet".

2.2.4.6. Daar is selfs geen Skrifbewyse vir vroulike diakens nie.

Dr. N. J. Hommes maak die stelling „Wordt de naam van presbyter en episcopus noch in het N.T. noch in de oud-christelijke kerk ooit verbonden met een vrouw, geheel anders staat het met de naam diakonos". Die Gereformeerde Kerke in Nederland het besluit „,various data point to a feminine branch of the diaconate". Daar word gewys dat Febe te Kenchreë 'n dienares (diakonos) van die gemeente was. Die sinode wys egter self daarop dat dit maar in die .,rigting van een vrouwelijke tak van het diaconaat" wys. Verder word daar met verwysing na Efese gesê dat vroue ,hoogstwaarschijnlijk onder de diakenen een aparte plaats" ingeneem het. Daar is dus ook geen duidelike uitspraak nie. Hierdie waarskynlikheid stut Hommes met die bewering dat die meeste ondersoekers van ons tyd aanvaar dat 1 Tim. 3 : 11 op 'n aparte kategorie van vroulike diakens wys. Tog is hy self so onseker dat hy van 'n ,soort vroulike diaken" praat. En in werklikheid is daar geen enkele afdoende bewys dat die Skrif vroulike diakens ken nie. Hoogstens kan aanvaar word dat daar ' $n$ vrouehulpdiens was.

Dis treffend dat almal wat uit die Skrif die bestaan van vroue diakens wil bewys met terme soos „hoogswaarskynlik”, „dit dui daarop", "dit wys in die rigting", „die meeste aanvaar”, ens., opereer. Sekerheid is daar nie. Aan die negatiewe kant staan egter die duidelike uitsprake van 1 Kor. $14: 34,35$ en 1 Tim. $2: 11-14$.

\section{Besluite van die G.E.S. in $\mathbf{1 9 6 8}$}

3.1. Die aanbevelings van die kommissie van preadvies op die studierapport was (art. 62):

3.1.1. "to make a study in depth of the entire question of office in the New Testament with a view to an enlarged recognition of the varied ministry of the New Testament Church (cf. Eph. $4: 12$, Romans 12, 1 Cor. $14: 12,23,26,31,39$ ) which varied character has not been historically developed within Reformed circles..."

3.1.2. dat die kerke ernstig besin in die lig van 1 Tim. $2: 12$, Ef. 5 : 22-24 en Gen. 2 : 18 ,wether or not at all ecclesiastical offices should be opened to women, taking into account her own nature and the nature of the congregation...";

3.1.3. dat die kommissie , are not convinced of the unity of the offices" en daarom is die uitsluiting van vroue in die regerende ampte geen verhindering om vroue as diakens te gebruik nie met die oog op ,the welfare of our Christian communions and as an outlet for the gifts and the energies of the qualified women of the 
church". (Hierdie laaste aanbeveling is veral belangrik omdat dit m.i. grotendeels die pragmatistiese en klerikalistiese benadering tot die probleem blootlê. $\mathrm{Ek}$ glo dit is die eintlike dryfveer agter die aangeleentheid.)

3.2. Die Sinode het egter nie die aanbevelings van hierdie kommissie wat reeds heelwat kritiek op die rapport van die deputate (C. van der Woude (s), N. J. Hommes, J. L. Koole, B. J. Oosterhoff en W. J. Grier) gehad het, aanvaar nie.

3.2.1. Die G.E.S. besluit om 'n studiekommissie te benoem ,to make a study in depth of the entire question of office in the New Testament, not neglecting the study of the varied ministry of the New Testament church as found in these texts: Ephesians 4: 12; Romans 12, 1 Cor. 14 : 12, 23, 26, 31, 39". Daar is streekskommissies benoem vir Noord-Amerika (ds. B. Nederlof, s.), Europa (prof. B. N. Oosterhof, s.), Suid-Stille Oseaan (ds. A. I. de Graaf, s.) en vir Afrika, met referent as saamroeper. Die rapporterende deputate vir die eersvolgende G.E.S. is dan voorgenoemde persone, behalwe prof. Oosterhof (Acta, art. 63).

3.2.2. In die plek van die tweede aanbeveling van die Kommissie (vgl. 3.1.2.) is besluit met 25 teen 22 stemme „That Synod declare that it is the plain and obvious teaching of Scripture that women are excluded from the office of ruling and preaching elders" (art. 64, 67). Die opmerklike in hierdie verband is dat die Gereformeerde Kerke in Nederland wat aan die kerke in SuidAfrika 'n ander besluit van die G.E.S. voorgehou het „inzake de rassenverhoudingen" in die verwagting dat dit „ook door $u$ zullen aanvaard en naar de intentie ... toegepast worden" (vgl. I. d. S., Des. '70, p. 3 v.) in weerwil van hierdie besluite die ouderling-en die predikamp vir vroue oopgestel het.

3.2.3. In die lig van die benoemde studiekommissie (vgl. 3.2.1.) is besluit dat „the basic question remained unanswered wether or not there is a basic created natural place and function of the woman subservient to the man, therefore, the R.E.S. is of mind that member churches should be cautious to proceed in the direction of the entrance of women into the diaconal office. Each church must make its own responsible evaluation of its situation and decision" (art. 81).

3.3. Die G.E.S. is deur die Geref. Kerke van Brasilië om 'n „opinion ... concerning the blessing given by elders" (Acta, p. 102) gevra. Die probleem ontspruit uit leesdienste by kleiner kerke. Tegelykertyd het dit te doen met, the nature of the offices, with the correlated questions of ordination and installation. The practice as such is only the consequence of such principle" (art. 183).

3.3.1. Hierdie vraagpunt het daartoe gelei dat die studiekommissie oor die vrou en die amp, ook opdrag ontvang het ,to adress itself specifically to the nature and essence of ordination and/or 
installation; and to the question as to what constitutes an office".

3.3.2. Die studiekommissie moet dan aanbevelings doen ,as to the proper practice which should be followed in our churches, as regards the functions, tasks, duties and/or privileges of the different (kinds of) office bearers, making the necessary allowance for exceptional circumstances".

3.3.3. Ondertussen word lede-kerke versoek om die status quo te handhaaf.

\section{Kritiese evaluering van die besluite en mandaat van die G.E.S.}

4.1. Die oorweldigende indruk wat 'n mens by die oorweging van voorgaande kry, is dat die G.E.S. in 1968 in totale verwarring en onsekerheid oor die hele ampskwessie verkeer het. Dit lyk asof daar nog nooit iets oor die amp duidelik was nie. Onwillekeurig vra 'n mens dan: is daar werklik nooit voorheen oor die amp besin nie - of het daar na die Tweede Wêreldoorlog 'n reusagtige grondverskuiwing in die kerkregtelike denke van Gereformeerdes plaasgevind, sodat al die besinning voor 1939 nou irrelevant, uitgediend, onaanvaarbaar en in elk geval as nie-bestaande beskou word? Dit is m.i. ' $n$ aanklag teen die G.E.S. dat hy nie tot besluite op die vraagpunte kon kom nie; nie bereid was om te volstaan met wat die eeue trotseer het nie totdat die teendeel bewys is nie.

4.2. Dit laat 'n mens dadelik vra na die prosedure wat die G.E.S. volg. In goeie gereformeerde kerkregering berus die bewyslas by diegene wat ' $n$ beswaar teen ' $n$ bepaalde gereformeerde uitspraak, besluit of praktyk het. In die G.E.S. het beswaarmakers egter geslaag om die hele gereformeerde wêreld te beweeg "to make a study in depth of the entire question of office in the New Testament..." asof die gereformeerde ampsleer nou eers Skriftuurlik getoets sal word. Onwillekeurig vra 'n mens of Calvyn nie al die hele kwessie in die vierde boek van sy Institusie bestudeer het nie - om maar net een van al die gereformeerdes te noem wat al ,a study in depth of the entire question of office in the New Testament" gemaak het. Ons weet dat die gereformeerdes al in die $16 \mathrm{e}$ eeu tot ' $\mathrm{n}$ belydenis oor die ampte gekom het (art. 30, 31 en 32 N.G.B.) en dit verder in hulle gemeenskaplike kerkorde uitgewerk het. Is die enigste moontlike werksame prosedure dan nie dat lede-kerke gravamina moet indien (en bewys) waarin wysiging en/of aanvulling van die Kerkorde (en formuliere vir die uitvoering van die Kerkorde) gevra word nie? Dit moet ons nie ten kwade gedui word nie as ons ernstig teen twee gevare wil waarsku: die moontlikheid dat 'n vraagpunt om 'n „opinion” by die G.E.S. 'n bepaalde orde en reformatoriese „practice" summier op losse skroewe stel; die verkeerde idee dat 'n wye en omvattende studie deur 'n aantal deputate punte van verskil waaroor die G.E.S. feitlik gelykop verdeel, sal oplos. Die feit dat die Nederlandse Gereformeerde Kerke besluit het om tog 
hulle eie weg te gaan, onderstreep hierdie afleiding.

4.3. Die aandag word gevestig op die negatiewe formulering van die oorspronklike mandaat in 1963 naamlik ,to examine in the light of Scripture the general Reformed practice of excluding women from the various ordained offices in the church".

Die mandaat impliseer dat die „Reformed practice” sonder 'n Skriftuurlike onderbou en dogma by Calvyn en ander reformatore ontwikkel het.

Die „practice” word negatief geformuleer as „excluding women”. Daar word nie positief aangevoer dat die Skrif die weg vir vroue open nie.

4.3.1. Die vraagpunt veronderstel reeds by implikasie diskriminasie teen die vrou op seksgronde. Haar posisie t.o.v. die ampte vertolk die vorige studiedeputate dus as „,inequality", ,second grade members” (bl. 147) „subordination” (bl. 159). Hierdie vertolking kan alleen gegee word, indien daar van 'n bepaalde twintigste eeuse filosofiese apriori oor die begrip "gelykheid" tussen manne en vroue uitgegaan word. Indien met ' $n$ ander uitgangspunt na die enersheid (,similarity") tussen man en vrou gevra word, verval die implikasie van ,inequality" in die lig van differensiasie. Kortom, 'n valse probleemstelling lei tot skewe gevolgtrekkings. Dit is opmerklik dat in die eeu van die liberalisme differensiasie tussen sekse sowel as tussen volke telkens as ongelykheid, heerskappyvoering, ens. vertolk word.

4.3.2. Die negatiewe probleemstelling na „excluding women” skep 'n vakuum, sodra 1 Kor. $14: 34$ en 1 Tim. $2: 12$ weggesyfer kan word. Dan is daar nie meer ' $n$ Skriftuurlike beletsel nie. ' $n$ Argumentum $e$ silentio kan dan sterk pleit vir toelating van die vroue, al is daar in die Skrif nog geen positiewe voorbeeld van vroue in die besondere ampte nie.

4.3.3. Die subjek vir die werkwoord ,excluding” is weer suiwer antroposentries. Dit veronderstel dat mense sommer vanaf die Reformasie vroue uitgesluit het. Daarmee doem die fundamentele vraag op: Wat is die ampte in die kerk? Indien die amp soos in die Deputaterapport voor die G.E.S. 1968 afgelei word uit 'n relasie tot die gemeente (,public functions", p. 148, „public actions”, p. 147, „public and private services", p. 155, „,special place”, p. 146, of selfs ,function" of selfs verbind word aan die "ministry of clergyman", p. 146) word die amp basies as 'n klerikale betrekking beskou waaroor die kerklike liggaam beskik (vgl. bv. die Lutherse ampsidee).

4.4. Letterlike uitvoering van die opdrag van die G.E.S. 1968 (art 183, 63, 81) is bykans onmoontlik. Verskillende uitgangspunte, filosofiese grondslae en benaderingswyses lei tot verskillende resultate. Dit sou meer as 'n boekdeel beslaan om ,in depth ... the entire question of office in the New Testament" te ondersoek, verskillende vertolkinge vanuit verskillende hoeke weer te gee, af te weeg en so enigsins gevolgtrekkings afdoende te motiveer. 
4.5. Die G.E.S. van 1968 het nietemin tereg opgemerk dat die beskouing (of belydenis?) van die amp an die wortel van die probleem lê. Daar is vroeër in die kerkreg (tema van die Doleansie) in gereformeerde kringe skerp gedebatteer oor kerkvergaderinge kerkraad, meerdere kerkvergaderinge, independentisme, kollegialisme, sinodokrasie, ens. Tans kom die stryd onder gereformeerdes al meer na vore oor die amp. - Dit was ook dié tema vir Calvyn teen die ,pousdom". Hierdie vraagstuk is grondleggend. Ons hoop om daaroor in ' $n$ volgende artikel 'n paar lyne te trek om die diskussie en besinning onder ons oor wat ek die ampsgeloof (en nie net 'n ampsidee nie) wil noem, te stimuleer.

B. Spoelstra.

(Na aanleiding van voordrag G.T.V. Pretoria, 1970) 